\title{
Study on the Development Process of One Bright Both Sides Dark Type Houses in China
}

\author{
Nan Zhou ${ }^{1}$, Masao Aoki², Shigeru Kamiwada ${ }^{3}$, Masaru Nishida ${ }^{3}$ and Hiroatsu Fukuda ${ }^{4}$ \\ ${ }^{1}$ Research Associate, Department of Environmental Engineering, Kitakyushu University, Japan \\ ${ }^{2}$ Visiting Professor, Xi'an University of Architecture and Technology, P.R. China \\ ${ }^{3}$ Professor, Department of Architecture, Faculty of Engineering, Kyushu Sangyo University, Japan \\ ${ }^{4}$ Associate Professor, Department of Environmental Engineering, Kitakyushu University, Japan
}

\begin{abstract}
The aim of this paper is to clarify the historical origin of the One Bright Both Sides Dark type of house which has odd-spans frontage and is considered as the typical and traditional unit of the planning composition of Siheyuan houses, and presents a new interpretation of the connection with the typical One Hall Two Insides type in Han dynasty. Further more, the authors attempt to clarify the appearance and development of One Bright Both Sides Dark type houses of China.
\end{abstract}

Keywords: China; traditional house; history; planning composition; development process; life style

\section{Introduction}

The purpose of this paper is to clarify the development process of the standard plan which composes the fundamental unit of SiHeYuan houses (四合院). SiHeYuan houses is one of the most popular houses in China, which have a courtyard surrounded with four buildings. Here we focus on several standard plan of the fundamental unit of SiHeYuan houses ${ }^{1}$.

It is said that the standard plan of the general fundamental units in Han dynasty (206BC.-220AD.) was One Hall Two Insides (一堂二内 : Yi Tang Er Nei) type, and the standard plan in Ming(1368-1644) and Qing dynasty(1644-1912) was One Bright Both Sides Dark (一明両暗:YiMingLiangAn) type. However, the standard plans between Han and Ming dynasty have not been examined thoroughly. It is unclear when One Hall Two Insides type appeared and became popular, and after that, through what kind of process, One Bright Both Sides Dark type appeared and became popular in Ming and Qing dynasty. There are several opinions about the fundamental units of One Hall Two Insides type in Han dynasty. One opinion considers it is Front Hall Back Room (前堂後室: Qian Tang Hou Shi) type. Another opinion considers it is One Bright Both Sides Dark type, the same type as Ming dynasty proposed by Itou Chuuta ( 伊東忠太).

There are several documents about the plan of Chinese ancient houses. However mostly they are indepandent and not well established systematically. And few of them

Contact Author: Nan Zhou, Research Associate, Dept. of Environmental Eng., kitakyushu University Hibikino1-1 Wakamatsu-ku, Kitakyushu, Fukuoka, 808-0135 Japan Tel: +81-93-695-3398(o) Fax: +81-93-695-3396(o)

e-mail: zhou@env.kitakyu-u.ac.jp

(Received May 8, 2002; accepted September 13, 2002) talked about the plan from the view of life style. In this paper we try to clarify the process of the development of planning composition by showing the process of developing the One Bright Both Sides Dark and its relation to One Hall Two Insides Dark in Han dynasty based on literature materials.

\section{Methods}

In China the houses of Ming, Qing dynasty still exist, but the clue to learn the style of houses before those dynasties is only in literature material and ruins. Although there are lots of descriptions about architecture in ancient literature from Zhou (1122-770BC.) to Han dynasty, most of them are about upper-class people's houses. Some paintings and painted stones with concrete expression of houses exist today, but we can only recognize the design and the structure of the buildings. It is true that there are lots of excavated ruins, but most of them are large-scale architectures such as palaces of reign classes. So it is very difficult to guess the house plans of the ordinary people. We studied the mainly ancient literatures of each dynasty and we analyzed the remains and excavated objects from the expressions in these literatural materials. In addition we referred to the study of Chinese houses as supporting date which was published recently.

\section{Fundamental Units of Han Dynasty \\ 3-1 One Hall Two Insides Type of Han Dynasty}

It is considered that the most common houses from Shang (1766-1122BC.)to Han dynasty were One Hall Two Insides type. There is a description in HanShu (漢 書), Mr:Zhao Cuo (昆錯) Biographyl) said that “When old emigrants built their house, they took One Hall Two Insides type for their house." It is the very popular literature in West Han dynasty in the story. Mr. Zhao Cuo proposed the emigrants to construct One Hall Two 
Insides type house. Then almost every family had their own houses of this type. There are some other descriptions as follows. "Even if I go through the gate, step on the hall, and go into the Room( 室), I can't find him anywhere" in LiJi/WenSang (礼記 / 問培 $)^{2)}$ written by KongZi (孔子), “He stepped on the hall, didn't go to the Room" in LunYu (論語), "He went on the hall to congratulate, went enter the Room to ask where he was going" in Qiu Hu poem (秋胡詩) in Nan Chao dynasty. In old time of china, Room( 室) means bedroom. The room other than bedroom had other names like Fan (房) or Tang( 堂). From those descriptions, we could guess that halls were separated from Rooms, and halls were used for ceremony or reception and Rooms were used for bedroom. It was described that upper class houses had a larger scale hall where parties could be held.

\section{3-2 Previous Opinion on the Standard Plan of One Hall Two Insides Type}

There are many descriptions to prove that One Hall Two Insides type was the typical house form in Han dynasty. The concrete plan of it could be interpreted below based on the past research.

\section{3-2-1 The Opinion that It is Front Hall Back Room Type}

The standard plan of One Hall Two Insides type recognized as Front Hall Back Room type is shown in Fig. 1. Chinese Residential Architecture History ${ }^{3)}$, written by Liu ZhiPing( 劉致平) says “The frontage of houses has two spans (1span means distance between two pillars), the hall has approximately two times larger than the bedroom. The plan of the house was shaped like a Chinese character of ' $⿴ 囗 十$ (Tian).' So 'Inside Person( 内 人),' means the person who is in 'Inside( 内 ),' is used for the other name of house wife." "China Architecture History and Building Method"4) written by LuLiuJun (盧毓駿) says “So called One Hall Two Inside" type means that halls were outside, and the rooms were inside. That could be the reason of the expression as "go UP the hall and go INTO the room( 登堂入室)" are often used. Usually hall didn't have south wall and open to the air. A kind of curtain would be used for the wall in winter. This type of houses is observed a lot in sculpture (Fig.2) or in architecture for ancestors or graves of Han dynasty.

\section{3-2-2 The Opinion that It is One Bright Both Sides Dark Type}

On the contrary there are few opinions said that the common houses of Han dynasty were recognized as One Hall Two Insides type. In Architecture history of Asia ${ }^{6}$, Itou Chuuta said that the typical houses in Zhou and ChunQiu (770-403BC.) dynasty, before Han dynasty, had a frontage of three spans. An entrance with door was at the center. And windows were at the right and left sides. Ordinary houses at that time also the same shape as this. This type is commonly used today. "Fig.3 is the imaginary drawing. Center is now used for reception room, right and left side rooms are used for living room and bedroom." History of Manners and Institutions in Han Dynasty ${ }^{7}$ has the same opinion. "The ordinary houses in Han dynasty had three spans frontage and called One Hall Two Insides type which is now commonly called One Bright Both Sides Dark type in Beijing." But both books were written long time ago. So the basis of their arguments was not clear. The existence of Front Hall Back Room type has already been proved by the archaeological discovery. So it is hard to assert that One Bright Both Sides Dark type is common type of ordinary houses in Han dynasty.

\section{3-3 The Origin of the Name of Front Hall Back Room and One Bright Both Sides Dark}

QiuGuLuLiShuo (求古録礼説) $)^{8}$ ) written by Jin E (金 鶚 1771-1819), vol.3 said that "If a room of the house faces the south, the room is Ming (明:bright), if it faces the north, the room is $A n$ (暗 :dark)." This is from the idea of YinYang (陰陽). If you suppose that Front Hall Back Room type is One Hall Two Insides, "Hall" faces the south, "Insides" face the north. In the YinYang theory,

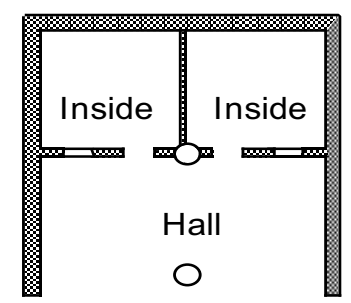

Fig. 1. The Image Plan of One Hall Two Insides Type Recognized as Front Hall Back Room Type

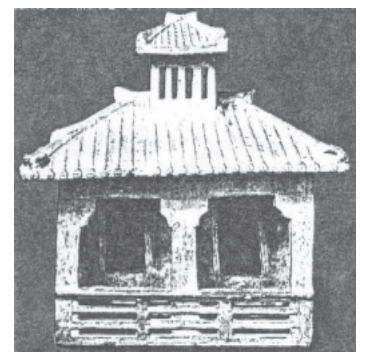

Fig. 2. Bronze Sculpture House of Front Hall Back Room Type (source: Reference 5), pp.119)

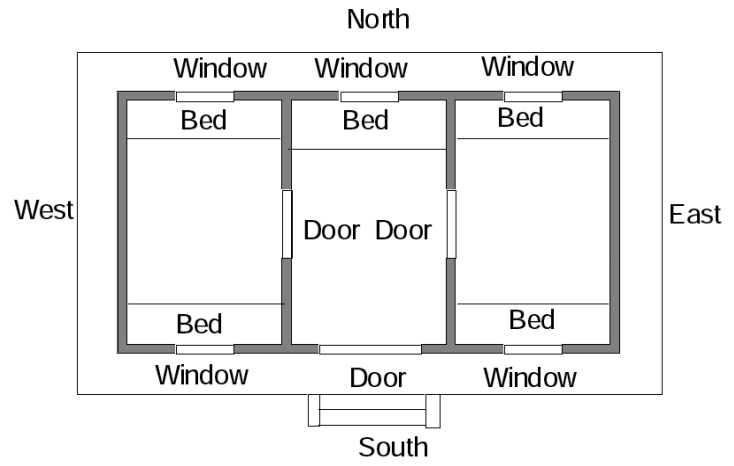

Fig. 3. The Typical House Plan in Zhou Dynasty by Itou Chuuta 
“Hall” means “Ming(明:bright),” “Insides” means “An (暗:dark)." So then One Hall Two Insides type corresponds to One Bright Both Sides Dark type. Also "If the depth of the hall is deep, the light doesn't reach inside the rooms" indicates that a hall was bright without a wall on the south and a room was closed and dark. Based on this expression, One Hall Two Insides also corresponds to One Bright Both Sides Dark. It is said that originally the name of One Bright Both Sides Dark is a slang used by common people. We counld see it in the folktales and novels of old times, but we can't find it in the technical literature of architecture. So we could guess that the upper class cultured people use the expression One Hall Two Insides and the ordinary people commonly used the word One Bright Both Sides Dark. So "Ming"and "An" came to mean living room and bedroom respectively.

\section{Two Kinds of Planning Form of One Hall Two Insides Type}

As we showed before, although the standard plan of One Hall Two Insides type is mainly considered Front Hall Back Room in Han dynasty, we confirmed another view point which was One Hall Two Insides type. In opposition to this confused fact recognition, we set up the hypothesis that both types coexisted and show the reason of coexistence based on the aspect of differences between the social classes.

\section{4-1 Upper Class Houses and Front Hall Back Room Type}

The standard plan of upper class houses from Zhou dynasty to Han dynasty was explained in KaoGongJi (考工記). “The Hall was front side, the room was backside, middle and both sides of the room were a kind of room. Front side hall was the place to meet subordinates, to hold a party, to use in ceremonies. Backside room was the place to lead daily life." The Chinese literature "Yuan Jian Lei Han( 淵監類函 )" says : in old time, when you build a house, the front half was open to the air and called "Hall(堂)." Back half was closed and called "Room(室)." The "Hall” is the room faces the south. Both expressions are Front Hall Back Room type. More detailed composition of rooms was restored in the reconstruction (Fig.4) based on the ancient material in Ceremony Figure (儀礼図) by ZhangHui Yan (張恵言) in Qing dynasty. It is no doubt that One Hall Two Insides type of Front Hall Back Room was commonly used in upper class in Han dynasty.

\section{4-2 Ordinary People and One Bright Both Sides Dark Type}

Such as Ceremony Figure, many Chinese ancient literature only described about the houses of upper class people like emperor officials. So the houses of poor people cannot be similarly identified as Front Hall Back Room type as well. Suppose their houses were also Front Hall Back Room type, there are several doubtful points. One is the question about the scale of houses. The

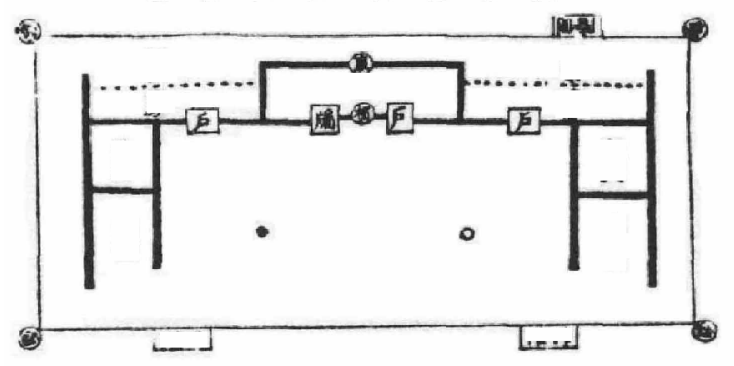

Fig. 4. Ceremony Figure by ZhangHuiYan (source: Reference 9) pp.50)

standard frontage of houses relates to the material of wood deeply. The length of wood has a large influence on the size of the frontage. In case of architecture and houses, the structure and size is limited been used. So the area of "Inside" of Front Hall Back Room type is $9 \mathrm{~m}^{2}$. The "Hall" has two times larger area, the size of a house is $36 \mathrm{~m}^{2}$ square shape, $6 \mathrm{~m}$ wide frontage, $6 \mathrm{~m}$ deep. The deeper the depth of the house is, inevitably the higher the eaves (top of the roof) are. The bigger and the longer beams and pillars are required. Ordinary people sould be very hard to afford this kind of house. So it is hard to assume that Mr. ZhaoCuo (昆錯) proposed the emigrants to construct this type of houses and it was used generally at that time. If they separated the space inside the house, the possibility to use a house long from side to side with shallow depth must be high. Here we see this type from the view of functional aspects, the "Hall" is front side, two times larger than "Inside," without south wall and needs a kind of curtain in winter, used for parties. This means the hall is for ceremony and reception. This reflects the life of upper class, the opportunity of ceremony or parties was few for ordinary people. They might be put their priority on economical or practical aspects of daily life, and they didn't need such a large halls.

From the archaeological aspect, because the houses of ordinary people were poor and humble, the remains were not found. That's why all of the excavated sculpture or the remains of Front Hall Back Room type belongs to upper class not ordinary people. If ordinary people used One Hall Two Insides type, "Inside" rooms would be put on the right and left side of "Hall," because the house becomes long from side to side with half depth, and the "Hall" becomes smaller. It would be easy to build, and the house fits both economical and practical requirements. So it is supposed that the One Hall Two Insides type for ordinary people was long sideways One Bright Both Sides Dark type.

Actually a sculpture in Han dynasty of long sideways houses with an entrance in the middle was excavated. (Fig.5) We cannot conclude that this is One Bright Both Sides Dark type, but it is clear that this is not Front Hall Back Room type and has long sideways plane.

\section{4-3 The Coexistence of Front Hall Back Room Type and One Bright Both Sides Dark Type}

As we mentioned above, in Han dynasty One Hall 
Two Insides houses were commonly used. There are two opinions about the standard plan. One is Front Hall Back Room type in which the hall and the room are arranged lengthways, the other is One Bright Both Sides Dark type in which the rooms are arranged long sideways. To choose only one opinion would be biased and partial. It would be proper to consider that both types coexisted. Upper class mainly used Front Hall Back Room type and ordinary people mainly used One Bright Both Sides Dark type. The name of One Bright Both Sides Dark would be a slang of One Hall Two Insides, then popular word for ordinary people. (Fig.6)

\section{The Existence of One Bright Both Sides Dark Type from Han to Ming, Qing Dynasty}

The standard plan of houses from Han to Ming, Qing dynasty has not been clarified. We found that One Bright Both Sides Dark type exist in this era, according to the old literatures. Here we showed the existence of this type in order of the dynasties.

\section{5-1 Jin Dynasty(265-420)}

Some literatures in Jin dynasty (little after Han dynasty) were found in which a kind of One Bright Both Sides Dark type house was described. According to ShiShuo (世説), “Luji (陸機) brothers lived in a 3 spans building in the working place, Mr. ShiLong lived in the 'East Head (東頭),' Mr. ShiHeng lived in the 'West Head (西頭)' separately." “Head" means the edge of buildings in architecture field ${ }^{10)}$. Then East Head and West Head indicate the both sides of the house. This means there were two bedrooms in each west and east side of the house. Also the house is 3 span frontage. So it is acceptable to consider this house was One Bright Both Sides Dark type, not Front Hall Back Room.

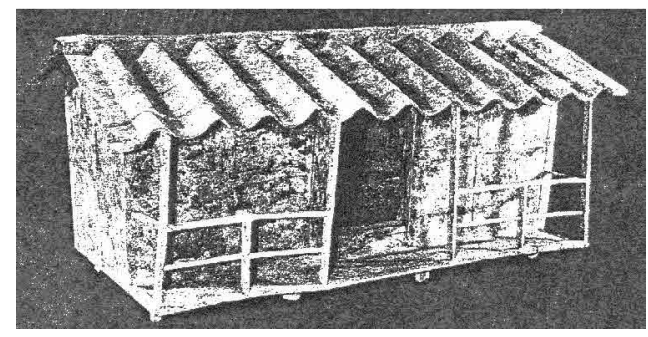

Fig. 5. Bronze Sculpture in Han Dynasty of Long Sideways (source: Reference 5) pp.118)
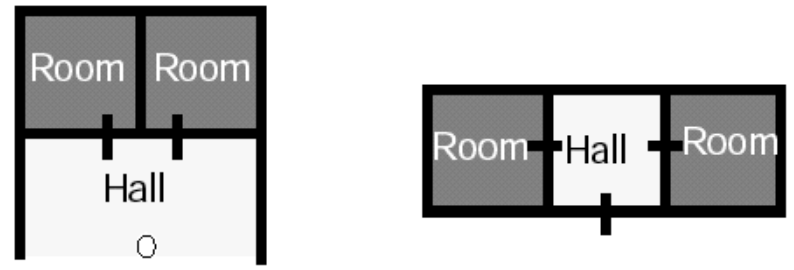

Fig. 6. Front Hall Back Room Type and One Bright Both Sides Dark Type of One Hall Two Insides

\section{5-2 Tang Dynasty (618-907)}

In JiYiJi (集異記) written by XueYongRuo (薛用弱) / Tang dynasty, there is the expression as follows. "One day Mr. WaJiXin (王積薪) stayed in a private house at ShuDao (蜀道), which was the border between the province of SiChuan (四川省) and ShaanXi (陝西省), in mountains. A mother-in-law and a wife lived together there. When the night came, the mother and wife closed and locked their doors to sleep. Mr. Wang couldn't sleep, then he heard a conversation from the hall. The motherin-law said to the wife, 'Let's have a game of Go.' The wife agreed. Mr. Wang was anxious about it. Because there was no light and candle in the hall, and they were in the east and west room respectively. Mr. Wang put his ear on the door and heard their conversation." It is clear from this description that the mother-in-law and wife lived separately in east and west room of the same building. From these words "in the hall" and "door" we can roughly get the idea about how the house plan looks like. You can guess that Mr. Wang was out side of the hall and put his ear on the door between outside and inside of the hall. But the house wasn't like One Hall Two Insides type of Front Hall Back Room. But the house wasn't like One Hall Two Insides type of Front Hall Back Room type. In YiQieJingYinYi (一切経音義), Mr. XuanYing (玄応)/Tang Dynasty wrote that "There was a difference between the hall and the room as if it is between outside the house above the ground stage and inside the room." Also the hall was open and with no door as you saw before. So the house must be long sideways One Bright Both Sides Dark type.

Also BaiJuYi (白居易 ), famous poet in Tang dynasty described his house as " 3 spans frontage with two pillars, two rooms with four windows." This should be "One Bright Both Sides Dark" type.

\section{5-3 Yuan Dynasty (1271-1368)}

In section 3 of JinFengChai (金鳳銰) written by ZhengTing Yu (鄭廷玉) said “If you don't have enough house rent fee to pay, I will have you live in 'ShaoJian (梢間),' not in the main room 'TouFang (頭房).", According to Classics Novel terminology Dictionary of China, this ShaoJian (梢間) is a kind of little side rooms which has a door to the central living room, bedroom or study room.

The clue of this dynasty is HouYingFang-SiHeYuan (後英房四合院) ruin which was discovered as the oldest SiHeYuan in Beijing ${ }^{11)}$. You could see that the plan of the main building is One Bright Both Sides Dark type (Fig.7).

\section{5-4 Ming Dynasty}

The oldest literature in which the words One Bright Both Sides Dark appeared was written in Ming dynasty. It was found in a famous novel JinPingMei ( 金瓶梅): Gold Jar Plum ${ }^{12}$. FeiCui House (翡翠軒) which is the house of Mr. XiMenQing (西門慶), the hero of the novel, to enjoy the cool of a summer evening in chapter 34, and the guest room in chapter 48, the room of Miss SunYueE 
(孫月娥) in chapter 58, the house of Miss ZhengAiXiang (鄭愛香) in chapter 59, they were all described as One Bright Both Sides Dark type in JinPingMei. This novel was about the story of a life of XiMenQing who was rich class man in ShanDong province (山東省) in Song dynasty. Because he was a fictional character, the model of so big house that the author referred to must be a typical house of middle and upper class in north of China. It can be assumed that almost all the other houses of this novel were also One Bright Both Sides Dark type. Fig. 8 is the restoration drawing of it, which we restored in $1991^{13)}$.

In chapter 36 of XiYouJi (西遊記) said "He went into the entrance of the Zen (禅) hall, inside was bright, four cane beds were inside rooms, ShaoJian (梢間 ).”

Those novels were written in Ming dynasty, but the time of the story was in Ming dynasty or Song dynasty. So the exact time of the houses in the story existed can not be clarified now, but at least in Ming dynasty One Bright Both Sides Dark type was used as a typical standard plan of middle and upper class houses.

\section{5-5 Qing Dynasty}

In Qing dynasty One Bright Both Sides Dark type houses appeared a lot in many literatures, such as HongLouMeng (紅楼夢). A lot of real houses in Qing dynasty still exist. In Qing dynasty the house style became established completely. It became clear that One Bright Both Sides Dark type existed in each dynasty from Jin to Qing dynasty.

\section{The Spread of One Bright Both Sides Dark Type}

As we mentioned above, both Front Hall Back Room and One Bright Both Sides Dark type coexisted in Han dynasty. On the contrary in Ming, Qing dynasty the house plan of Front Hall Back Room type was not recognized, and One Bright Both Sides Dark type became popular. Neither the real house of Front Hall Back Room type can be found today. Front Hall Back Room type declined with some reasons from Han and following dynasties, and One Bright Both Sides Dark type gradually spread. One of the reason that One Bright Both Sides Dark type spread was the transition of Chinese life style from sitting-on-floor style to sitting-on-chairs style. The number of spans between pillars was commonly even number in Zhou, Qin(221-206BC.), Han dynasty as the style to emphasis a center axis of buildings. That means to put pillars on the center axis and to have spans between pillars right and left side symmetrically. But this style became inconvenient for putting ancestral mortuary tablets or chairs and furniture at a center of a hall. Gradually to put a span in the center of building and have pillars symmetrically both sides, and the number of spans became odd number ${ }^{14)}$. That's why One Bright Both Sides Dark type which has the odd number number of pillars is symmetrical became popular gradually.

The time of transition from sitting-on-floors style to sitting-on-chairs in China corresponded to the time of transition from Front Hall Back Room to One Bright Both Sides Dark ${ }^{15)}$. When sitting-on-floors style was popular in Han dynasty, Front Hall Back Room was also popular. When the sitting-on-chairs spread in Song and Ming dynasty, One Bright Both Sides Dark replace of Front Hall Back Room.

In Ming and Qing dynasty One Bright Both Sides Dark type was completely established as the most formal house plan unit, and introduced in many upper class houses in Metropolitan Beijing.

\section{Conclusion}

Although standard plan of One Hall Two Insides type houses in Han dynasty was generally considered as Front Hall Back Room type, we proposed in this paper that both Front Hall Back Room and One Bright Both Sides Dark would coexist. The name One Bright Both Sides Darkwas the slang of One Hall Two Insides, used among ordinary people. Both One Bright Both Sides Dark and One Hall Two Insides had meant both Front Hall Back Room and long sideways One Bright Both Sides Dark. As the sitting-on-floors style changed to the sitting-onchairs style, One Bright Both Sides Dark type diffused gradually in place of Front Hall Back Room type. One Bright Both Sides Dark type became popular to fit in the

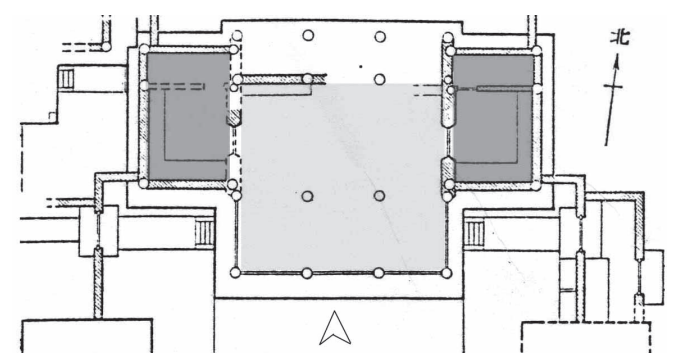

Fig. 7. HouYingFang-SiHeYuan Ruin of Yuan Dynasty (source: Reference 11))

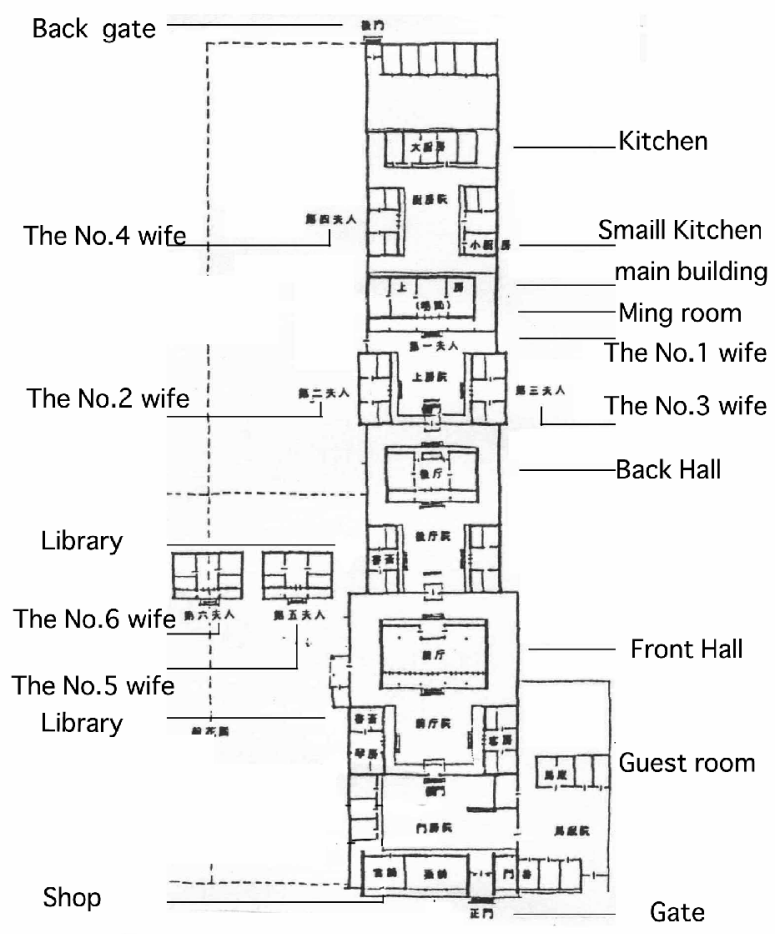

Fig. 8. The House Plan of XiMenQing in JinPingMei 
sitting-on-chairs style and used for the fundamental unit of SiHeYuan houses.

\section{Acknowledgments}

The authors would like to thank Professor Zhou Ruoqi, the Director of Architecture Institute, Xi' an university of Architecture and Technology, China, and Mr. Liu yanhui and Mr. Liu dongwei of China Ministry of Construction, for their great cooperation in the field survey. Thanks are also extended to graduate student Mr.Tatsuaki Taniyama for inputting data.

\section{Notes}

1. The following figure is the typical plan of "SiHeYuan" houses. The fundamental unit which composes each building is clearly "One Bright Both Sides Dark” (一明両暗 : YiMingLiangAn) type in this figure.

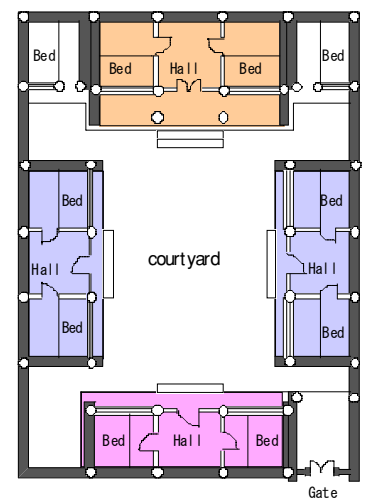

\section{References}

1) BanGu, Han dynasty, Hanshu.

2) KongZi, ChunQiu dynasty, LiJi/WeSang.

3) LiuZhiping (1990) Chinese Residential Architecture History, China architecture industry publishing company.

4) LuLiujun (1971) China Architecture History and Building Method, LuLiujun published, Chinese Taiwan.

5) WangQiJun (1992) Vernacular Dwellings, A Series of Ancient Chinese Architecture, China Architecture \& Building Press.

6) Itou Chuuta: Architecture History of Asia, Hara Book store, pp.83-85.

7) Qu,Duizhi (1991) History of Manners and Institutions in Han dynasty, ShangHai Art and Literature Publishing Company, pp.256.

8) JinE, Qing dynasty, QiuGuLuLiShuo.

9) Itou Chuuta, China Architecture Ornament, China, Vol.1, Hara Book Store, 1983.

10) Tanaka Tan (1989) Architecture History of China, Kobundo, pp.1-176.

11) YuanDaDu Archaeology Group (1972) Beijing HouYingFang Yuandynasty Residence Ruin, Archaeology, No.6, Science Publishing Company, pp.2-7.

12) XiaoXiaosheng (1677) Embroidery Picture JinPingMei.

13) Aoki, Masao et al.(1991) A study on living style of SiHeYuan houses in end of the 16th and 20th century beginning, the 3, Summaries of Technical Papers of Annual Meeting Architectural Institute of Japan, 1-2.

14) YangHongXun (1987) Architecture Archeology proceedings, Civilization Publishing Company, pp.75.

15) Bin Li, Kunio Funakoshi et al. (1999) A Study on Changing Process of Sitting Styles in China, Journal of Architecture, Planning and Environmental Engineering, No.518, AIJ, pp.145-151. 